\title{
PEMBAHARUAN SISTEM PENDIDIKAN PONDOK PESANTREN AL-ANWARIYAH DALAM MENGHADAPI MODERN DI TEGAL GUBUG LOR KABUPATEN CIREBON
}

\author{
Kambali \\ Fakultas Agama Islam, Universitas Wiralodra \\ E-mail: kambaliibnu@gmail.com
}

\begin{tabular}{|c|c|c|}
\hline Received & Revised & Accepted \\
\hline 10 Januari 2021 & 10 Februari 2021 & 28 Maret 2021 \\
\hline
\end{tabular}

\section{INNOVATION OF EDUCATIONAL SYSTEM OF AL-ANWARIYAH BOARDING SCHOOL TO CONFORT THE MODERNIZATION}

\begin{abstract}
:
This study aims to analyze the role of Islamic boarding schools in facing increasingly complex modernization. This study uses a qualitative method. The results show that the success of achieving this success is very much determined by the renewal of the boarding school education system which includes various forms and types, such as teaching methods, curriculum, administration and availability of facilities and infrastructure. In this regard, the Al-Anwariyyah Islamic boarding school has made many reforms regarding the education system. And related to that, the scope studied in the education system includes teaching methods, curriculum, administration and infrastructure.
\end{abstract}

Keywords: boarding school, modernity, and education reformation.

\begin{abstract}
Abstrak
Penelitian ini bertujuan untuk menganalisis peran pondok pesantren dalam menghadapi modernisasi yang semakin kompleks. Penelitian ini menggunakan metode kualitatif. Hasil menunjukan bahwa keberhasilan pencapaian keberhasilan tersebut sangat ditentukan akan adanya pembaharuan system pendidikan pondok pesantren yang meliputi berbagai bentuk dan jenisnya, seperti metode pengajarannya, kurikulumnya, administrasinya dan tersedianya sarana dan prasarana. Berkaitan dengan hal tersebut, pondok pesantren Al-Anwariyyah telah banyak mengadakan pembaharuan mengenai system pendidikan. Dan berkaitan dengan itu pula maka lingkup yang dikaji dalam sistem pendidikan meliputi metode pengajarannya, kurikulum, administrasi dan sarana prasarana.
\end{abstract}

Kata kunci: pondok pesantren, modernisasi, dan reformasi pendidikan. 


\section{Pendahuluan}

Pembaharuan pendidikan sebagai perspektif baru dalam². Demikian pula pembaharuan sistem pendidikan pondok pesantren, yang umumnya masih dijadikan model pendidikan Islam yang tertua di Indonesia. Dari kenyataan tersebut diatas, pondok pesantren dalam menjalankan tugasnya sebagai lembaga pendidikan banyak mendapat tantangan,baik dari luarmaupun dari dalam pesantren sendiri terutama dari masyarakat modern yang beranggapan bahwa pondok pesantren telah jauh ketinggalan jaman ${ }^{2}$, tidak sesuai dengan kebutuhan masyarakat yakni dengan putaran zaman.

Sebagaimana telah diungkapkan Suryopratondo bahwa : Menyadari adanya kelambataan perkembangan pondok pesantren bila dibandingkun dengun lembaga pendidikan lainnya dimasa mutakhir ini, nampaknya dari lingkungan pesantren sendiri terdapat arus yang semakin kuat untuk mengadakan pembaharuan. Seperti Madrasah Ibtidaiyah ( MI )3. Madrasah Tsanawiyah ( MTs) dan Madrasah Aliyah (MA), baik yang berstatus swasta maupun negeri. Dan bahwa beberapa pesantren sudah ada lembaga pendidikan umum. Namun kita ketahui bahwa kemempuan pesantren yang berada di pedesaan, sebagaimana diungkapkan bahwa keinginan untuk mengadakan pembaharuan ialah bahwa pengakuan pelajaran dan pendidikan di pondok pesantren yang di dalamnya terdapat madrasah atau pendidikan dan pengajaranya diberikan dengan sistem madarasah.

Secara hirarki perubahan tersebut memang harus ada dan merupakan kebutuhan agar lulusan pesantren tidak hanya mampa menguasai ilmu-ilmu agama saja, akan tetapi lebih jauh dari itu mereka harus mampu menagantisipasi perubahan-perubahan yang terjadi dimasyarakat, mampu menyikapi perubahan $\urcorner^{-}$ perubahan tersebut secara islami,disamping itu out put pesantren juga memiliki keilmuan yang luas baik dari aspek kognitif, psikomotorik dan afektif yang dapat diapresiasikan dalam kehidupan sehari-hari.

Tujuan terbentuknya pesantren adalah membimbing anak didik untuk menjadi manusia yang berkepribadian islam dan dengan ilmu agamanya ia sanggup menjadi mubalig islam dalam masyarakat sekitar melalui ilmu dan amalnya. Hal ini sebagaimana dalam ayat Al - Qur'an surat An-Nahl ayat 125

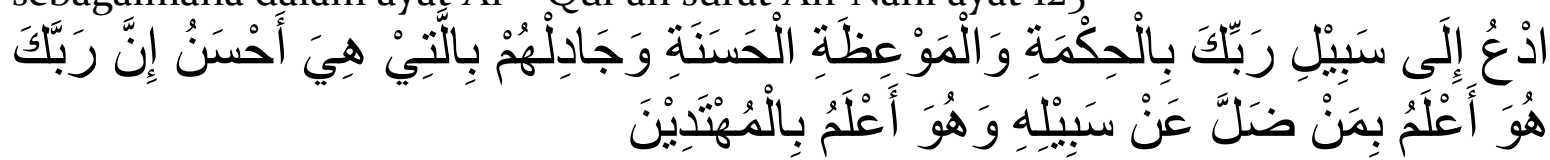

"Serulah (manusia) kepada jalan Rabbmu dengan hikmah dan pelajaran yang baik dan bantahlah mereka dengan cara yang lebih baik. Sesungguhnya Rabbmu Dia-lah yang

\footnotetext{
${ }^{1}$ Kambali Kambali, "PERTUMBUHAN DAN PERKEMBANGAN EMOSIONAL SERTA INTELEKTUAL DI MASA PRENATAL," Risâlah, Jurnal Pendidikan dan Studi Islam 4, no. 2, Sept (2018): 129-148.

2 M Syaifuddien Zuhriy, "Budaya Pesantren Dan Pendidikan Karakter Pada Pondok Pesantren Salaf," Walisongo: Jurnal Penelitian Sosial Keagamaan 19, no. 2 (2011): 287-310.

${ }^{3}$ Suparlan Suryopratondo, Kapita Selekta Pondok Pesantren, vol. 1 (Paryu Barkah, 1976).
} 
lebih mengetahui tentang siapa yang tersesat dari jalan-Nya dan Dia-lah yang lebih mengetahui orang-orang yang mendapat petunjuk". (QS. 16:125)

Agar pesantren tidak kehilangan nilai dan kharismanya sebagai akibat adanya pergeseran fungsi tersebut, maka pesantren harus berbenah diri secara serius, sehingga animo masyarakat tetap harum, dan pesantren sebagai salah satu lembaga pendidikan islami juga harus memiliki peranan yang sangat strategis dalam menghadapi tantangan modernisasi ${ }^{4}$.

Bentuk dari latar belakang tersebut peneliti tertarik untuk mengetahui lebih jauh bagaimana sistem pendidikan yang dipakai saat ini dipondok pesantren AlAnwariyyah tegalgubugLor Arjawinangun Cirebon dari dimulai dirintisnya pondok ini sampai sekarang.

Oleh karena itu, dasar pemikiran di atas mendorong peneliti untuk mengkaji lebih jauh tentang masalah-masalah yang berkaitan dengan pesantren ,terutama tentang sistem pemabaharuan pendidikannya dalam menghadapi tantangan modernisasi. Dan merupakan pertimbangan yang matang. Dan penelitian ini dipusatkan di Pondok Pesantren Al-Anwariyyah Tegalgubug Lor Kec. Arjawinangun Kab. Cirebon.

\section{Metode Penelitian}

Ada dua pendekatan yang peneliti gunakan dalam pembahasan penelitian ini antara lain : (a) Pendekatan teoritis, yaitu dengan membaca dan mengkaji lebih dalam buku-buku yang berkaitan dengan obyek penelitian, sebagai kerangka landasan berpikir ${ }^{5}$, yang kita kenal dengan istilah library research, dan (b) Pendekatan empiris,yaitu mengamati apa yang terjadi dilapangan sebagai landasan untuk memperoleh data empiris disebut dengan field reserch.

Dalam hubunganya dengan pembahasan pembaharuan sistem pendidikan di Pondok Pesantren al-Anwariyyah. maka analisis data penelitian ini memakai analisa kulitatif, dengan mengidentifikasikan beberapa masalah dengan di titik beratkan pada aspek-aspek sebagai berikut : (a) Pengembangan dan Pembinaan metode mengajarnya, (b) Pengembangan dan Pembinaan Kurikulumnya, (c) Pengembangan dan Pembinaan administrasinya, dan (d) Pengembangan dan Pembinaan sarana dan fasilitasnya.

\footnotetext{
${ }^{4}$ Prima Prayitno, "PEMBERDAYAAN SUMBER DAYA SANTRI MELALUI ENTREPRENEURSHIP DI PONDOK PESANTREN AL-ASHRIYYAH NURUL IMAN ISLAMIC BOARDING SCHOOL PARUNG- BOGOR," Quality, 4, no. 2 (2016).

${ }^{5}$ Sugiyono, Metode Penelitian Kuantitatif Kualitatif Dan R \& D (Bandung: Penerbit ALFABETA, 2011).
} 


\section{Hasil Penelitian dan Pembahasan \\ Dasar dan Tujuan Pondok Pesdantren Al-Anwariyyah}

\section{Dasar Pondok Pesnatren Al-Anwariyyah}

Dasar yang melandasi berdirinya pondok pesantren Al-anwariyyah adalah Al-Qur' un Dan A I-Hadits memalui kitabullah dan sunah Rasul. Inilah yang menjadi dasar sekaligus sumber semua aktifitas dipendidikan pondok pesantren Al-anwariyyah ini untuk mencapai tujuan yang diinginkan

\section{Tujuan Pondok Pesantren Al-Anwariyyah}

Setiap aktifitas manusia baik yang dilaksanakan oleh seorang atau sekelompok orang tertentu memiliki suatu tujuan tertentu. Karena itu segala daya dan dana selalu diharapkan untuk mencapai tujuan tersebut. Demikian juga dengan pelaksanaan pendidikan baik yang bentuk formal maupun non formal serta informal, hanya saja bedanya, kalau dilembaga pendidikan formal memiliki tujuan yang telah dirumuskan secara jelas sehingga baik guru maupun siswa dapat mengetahuinya, sedangkan dilembaga pendidikan non formal dan informal tidak demikian.

Pondok pesantren sebagai lembaga pendidikan non formal pada hakekatnya mempunyai tujuan yang sama yakni untuk terealisasinya syiar islam dibumi.

Ketika diadakan wawancara dengan pimpinan pondok pesantren KH.Rokhmatullah mengatakan bahwa tujuan pendidikan dipondok pesantren Al-anwariyyah adalah untuk merealisasikan perintah Allah yang termaktub dalam Al-Qur'an surat Ali Imron yang berbunyi :

"Dan hendaklah ada diantara kamu segolongan umat yang menyeru kepada kebajikan, menyuruh kepada yang ma'ruf dan mencegah dari yang mungkar, merekalah orang-orang yang beruntung"

Selain ayat tersebut diatas, a da hadits Nabi yang dijadikan dasar pendidikan di Pondok Pesantren Al-anwariyyah adalah sebuali Hadits Shoheh dengan sanad dari abu Hurairah RA :

"Siapa yang ditanya tentang suatu ilmu kemudian ia menyembunyikaannya, niscaya Allah mengekangnya dengan kekangan dari api neraka"

Dari ayat dan Hadits diatas maka, tujuan Pondok Pesantren alAnwariyyah menurut K.H. Anwar Amin adalah penyebaran, pengajaran dan pendidikan Syariat Islam yang diamanatkan dari nabi Muhammad SAW dalam rangka mencetak insan - insan yang beriman dan bertaqwa serta memiliki ilmu pengetahuan yang luas.

Bila dirumuskan maka tujuan Pondok Pesantren al-Anwariyyah adalah untuk menceta.k insan sholeh, berilmu dan beramal, bertaqwa dan berahlak luhur berdisiplin dan mempunyai kepribadian muslim yang berlandaskan pada Al - Qur'nul Karim dan Al - Hadits.

\section{Aktifitas Kependidikan}


Pondok pesantren sebagai lembaga pendidikan yang mengutamakan pendalaman agama Islam, yang secara spesifik untuk mendidik santri menjadi kader kyai

Berdasarkan keadaan diatas jelas bahwa pendidikan di pondok pesantren harus berorientasi pada kebutuhan masyarakat, dalam artian segala apa yang diajarkan dipondok pesantren harus mampu menyiapkarn para santri menjadi kader pembangunan masyarkat.

Pondok Pesantren al-Anwariyyah sudah termasuk lembaga pendidikan yang maju dilingkungan kecamatan Arjawinangun. Kalau pada mulanya pondok pesantren al-Anwariyyah menetapkan tujuanya untuk mencetak kader-kader ulama tetapi saat ini sudah mulai diperluas dengan maksud mendidik paras santri agar nantinya mau mengembangkan dirinya, dapat berilmu amaliyah dan beramal ilmiyah sehingga tercetak kader-kader ulama intelektual yang berarti ulama yang memiliki pengetahuan umum disamping juga memiliki pengetahuan agama.

Sedang pesantren al-Anwariyyah sudah mampu mengembangkan suatu aktifitas pendidikanya yaitu dalam bentuk Madrasah Diniyah yang merupakan suatu perguruan tersendiri dan dipimpin oleh seorang kepala sekolah dan dibantu oleh beberapa orang guru, namun selama ini yang menjadi kebanggaan bagi para santri adalah santri juga diberi kebebasan untuk belajar ilmu pengetahuan umum baik didalam maupun diluar pondok pesantren al-Anwariyyah.

Pada masa perkembangan yang terakhir kegiatan belajar mengajar di pesantren al-Anwariyyah sangat pesat, maju dan materi pelajaran juga bertambah. Adapun cara belajar yang disampaikan oleh pengasuh atau Kyai sistem penyajian materi pelajaran ada tiga cara yaitu :

a. Cara sorogan dimana santri seorang demi seorang menghadap guru dengan membawa kitab yang dipelajari, kemudian kyai membacakamya, sistem ini dipakai umntuk mengaji Al-Qur'an baik yang masih belajar binadzor maupun bilghoib.

b. Secara Weton dimana para santri mengikuti pengajian secara kuliah, santri meyimak kitabnya masing-masing dan membuat catatan, sistem ini dipakai untuk belajar di madrasah diniyah dan pengajian kita-kitab kuning lainnya.

c. Secera berkelompok, yakni dengan cara bersama.-sama dan ada kalanya santri diajar meniruaknya, sistem ini dipakai dalam pelajaran diniyah.

\section{Penyelenggaraan pendidikan di Pondok Pesantren al-Anwariyyah}

Didalam melaksanakan programnya lembaga pendidikan pondok pesantren al-Anwariyyah menyediakan :

\section{a. Pengelolaan Pendidikan :}

1. TKA Al-Anwariyah

2. TPA Al-Anwariyah

3. MDA Hidayatul Mubtadiin

4. MI Hidayatul Mubtadiin 
5. MTs Hidayatul Mubtadiin Putra

6. MTs Hidayatul Mubtadiat Putri

7. MA Hidayatul Mubtadiin Putra

8. MA Hidayatul Mubtadiat Putri

9. Wajar Dikdas Salafiyah

10. Robithoh

b. Pengelolaan Nisyatot :

1. Jampus \{Syarif Hidayatullah\}

2. Jam'iyah Far'iyah

3. Musyawarah Takror

4. Mudzakaroh

5. Pengajian Sorogan

6. Pengajian Bandongan

7. Pengajian al-Qur'an

8. Mukhafadzoh

9. Bahtsul Kutub

10. Tadarus al-Qur'an

11. Qiroatul Kutub

12. Kursus Komputer

c. Keterampilan

1. LKK ( Latihan Keterampilan Keliling )

2. Menjahit ( Pakaian dan Bordir )

d. Koperasi Pondok Pesantren :

1. Membentuk dan mendirikan Kopontren al-Anwariyyah

2. Membentuk unit-unit usaha dalam naungan Kopontren al-Anwariyah

3. Koperasi Pesantren menyediakan kitab-kitab dan keperluan santri atau siswa juga membantu santri yang kehabisan uangnya.

\section{Pembahasan mengenai Analisa Data}

Berdasarkan pada hasil penelitian yang penyusun lakukan dipondok pesantren al-Anwariyyah tersebut selama mengadakan penelitian kurang lebih lima belas hari, dan sesuai dengan judul penelitian ini yaitu PEMBAHARUAN SISTEM PENDIDIKAN PONDOK PESANTREN AL-ANWARIYYAH. Dan dalam pembahasan ini peneliti akan menganalisa sesuai dengan fokus penelitian yakni ada empat aspek yang akan peneliti sajikan dalam penelitian ini yaitu :

1. Penyempurnaan metode pengajaranya

2. Penyempurnaan kurikulumnya

3. Penyempurnaan administrasi

4. Penyempurnaan sarana dan fasilitasnya

Metode yang peneliti gunakan dalam memperoleh data diatas adalah metode observasi langsung wawancara atau interview dan metode dekumenter terhadap arsip-arsip pondok pesantren al-Anwariyyah.

Adapun analisa data yang penyusun gunakan dengan memperhatikan masalah yang diteliti, tujuan penelitian dan jenis yang ada, maka metode analisa yang digunakan dalam penelitian ini adalah untuk data yang bersifat kualitatif, dianalisa dengan menggunakan deskriptif dan tehnik inilah yang 
banyak peneliti gunakan dalam mengkaji masalah penelitian.

Dalam pembahasan ini peneliti membahas masalah-masalah pembaharuan sistem pendidikan di pondok pesantren yakni dipondok pesantren al-anwariyyah. Dan sebagaimaan uraian terdahulu hahwa pengertian sistem pendidikarn disini tidak mencakup semua aspek yang termasuk kategori sistem, akan tetapi sistem disini hanya difokuskan pada metode pengajaran, kurikulum, administrasi dan fasilitas atau sarana pendidikanya.

Untuk mengetahui proses perkembangaa pembaharuan sistem pendidikan dipondok pesantren al-Anwariyyah dapat dijabarkan sebagai berikut :

\section{Penyempurnaan metode pengajaranya.}

Berdasarkan pada penelitian yang peneliti lakukan maka dalam melaksanakan metode pengajaran yang dipakai oleh pondok pesantren alAnwariyyah dapat digolongkan sebagai pondok pesantren yang banyak mengalami proses pergeseran atau pengembangan.

Sistem pengajaran yang diterapkan di pondok pesantren alAnwariyyah pada mulanya tidak diklasifikasi dalam tingakatan-tingakatan berdasar jenjang sebagaimana dalam sistem sekolah atau sistem madrasah, sementara itu sistem pengajaranya menggunakan bandongan dan sorogan saja, yang tidak lain merupakan pola tradisonal, dimana kemajuan seorang santri diukur oleh kecerdasanaya dalam menyelesaikan pelajaran yang disampaikan dan metode yang dipakai dalam penyampaian mata pelajaranya hanyalah dengan menggunakan metode harfiyah salafiyah saja yang lazim disebut dengan pengajaran utawi, iki, iku.

Terjadinya perubahan dalam sistem pengajaran di pondok pesantren al-Anwariyyah adalah berkat pemikiran pengasuh pondok yaitu K.H. Rokhmatullah dan K.H. Aly Shofwan sebagai tenaga pengelola.

Ketika penelitian ini dilakukan, pondok pesantren al-Anwariyyah adalah sudah diwarnai dengan 3 corak pendidikan yaitu :

1. Pendidikan keagamaan

2. Pendidikan Madrasah

3. Pendidikan keterampilan

Sementara perubahan vang cukup mendasar dalam metode pengajaran di pondok pesantren al-Anwariyyah adalah berkaitan dengan ditambahnya metode pengajaran dengan beberapa metode yang dilakukan oleh K.H. Ali Shofwan sehubungan dengan dibukanya beberapa lembaga pendidikan baru di pondok pesantren al-Anwariyyah. Kalau sebelumnya sistem pengajaran yang dilakkan hanyalah dengan sistem sorogan atau bandongan maka oleh K.H. Rokhmatullah yang dipercaya untuk mengelola pondok dilengkapi dengan sistem, diantaranya sistem musawaroh, sistem mudzakaroh, sistem tahasus dan sistem klasikal.

Dikala peneliti mengadakan wawancara dengan K.H. Rokhmatullah beliau mengatakan bahwasanya perubahan atau pemhaharuan ini pada dasarnya merupakan suatu upaya untuk menutupi kelemahan sistem pengajaran yang sudah ada, karena sistem sorogan dan bandongan saja 
tidak akan sesuai lagi jika diterapkan pada sistem pendidikan madrasah. Dan penggunaan metodenya tidaklah mungkin hanya mengandalkan satu bentuk metode apabila bentuk metode harfiyah safahiyah, untuk bentuk semua pengajaran di lembaga pendidikan yang ada sistem madrasahnya. sehingga yang dipakai dalam proses belajar mengajarnya di pondok ini dilengkapi dengan beberapa metode antara lain dilengkapi metode ceramah, tanya jawab, demonstrasi, pemberian tugas dan metode driil.

Adapun alasan dan manfaat dilakukannyaa perubahan dibidang metode pengajaran $\mathrm{KH}$ Anwar Amin mengatakan bahwa dengan dilakukannya perubahan atau pembaharuan diharapkan :

1. Para santri memahami betul apa yang dilakukan oleh seorang guru atau ustadz

2. Para santri dituntut untuk mampu berfikir sendirian dan dapat mengembangkan sendiri .

3. Agar antara guru dan santri aktif

4. Agar para santri dapat belajar secara independen

5. Agar para santri dapat melaksanakan latihan - latihan untuk mengembangkan kecakapan dan ilmu pengetahuannya sesuai dengan ilmu pengetahuannya

6. Agar para santri bisa untuk segera memecahkan masalah.

\section{Penyempurnaan kurikulumnya}

Istilah kurikutum tidak ditemukan datam kamus sebagian pesantren terutama pada masa sebelum kemerdekaan walaupun materinya sudah ada dalam praktek pengajaran, bimbingan rohani, dan latihan kecakapan dalam kehidupan sehari-hari di pesantren, yang merupakan satuan dalam proses pendidikan di pesantren itu sendiri. Hal tersebut disebabkan memang pondok pesantren lama mempunyai kebiasaan untuk tidak merumuskan dasar dan tujuan pendidikan secara eksplisit, ataupun meruncingkannya dengn tajam dalam bentuk kurikulum, dengan pelajarannya dan masa belajarnya.

Terjadinya pembaharaan di pondok pesantren al-Anwariyah dalam kurikulumnya dilakukan oleh K.H. Aly Shofwan yang mendapat kepercayaan dari K.H. Rokhmatullah untuk mengelola pengajaran yang ada di pondok pesantren al-Anwariyyah, dengan dibantu oleh pengurus dibidang pendidikan seperti K.H. Zuber Zen dan $\mathrm{Ny} \mathrm{Hj}$. Musa'adah yang mendapat kepercayaan pula dari K.H. Rokhmatullah. untuk membantu merumuskan kurikulum.

Adapun bentuk-bentuk pembaharuan yang dilakukan dipondok pesantren al-Anwariyyah dalam bidang kurikulum yaitu diadakannya kurikulum lokal maupun kurikulum Departemen Agama RI yang mana pada masa-masa awal dipondok pesantren ini tidak dirumuskannya kurikulum karena pada wxktu itu terbawa oleh sifat kesederhanaan pondok pesantren dimana K.H. Ahmad Amin mengajar dan santrinya belajar semata-mataa ibadah karena Allah dan tidak pernah dihubungka.n dengan tujuan tertentu dalam lapangan penghidupan atau tingkatan dan jabatan tertentu. 
Walaupun ada target yang akan dicapai di pondok pesantren adalah menjadi insan mu'min, muslim, 'alim dan soleh. Jadi pada waktu belum dirumuskan sebenarnya kurikuluin pesantren secara tidak langsung sudah ada yaitu yang meliputi seluruh kegiatan yang dilakukan selama sehari semalam.

Maksud dan kegunaan dilakukannya pembaharuan dalam bidang kurikulum menurut K.H. Rokhmatullah dan K.H. Aly Shofwan karena melihat perkembangan dan perubahan yang terjadi dimasyarakat terutamaa masyarakat modern, dalam berbagai bidang baik itu politik, ekonomi, pendidikan. Jadi pondok pesantren ini dituntut untuk menggunakan kurikulum yang sesuai dan menyesuaikan diri dengan perkembangan yang terjadi, kegunaan dilakukan pengembangan dibidang kurikulum untuk memudahkan proses belajar mengajar yang dilakukan dipondok pesantren al-Anwariyyah.

Perubahan dipondok pesantren al-Anwariyyah tentang dirumuskannya kurikulumnya tidak mengalami kesulitan, pada mulannya memang banyak tantangan yang timbul baik dari masyarakat maupun dari lingkungan pondok pesantren al Anwariyyah itu sendiri. Masyarakat pernah menolak dimasukannya ilmu umum dan pemakaian metode baru yang tidak lazim itu, karena mereka mengaaggap hal ini menghilangkan kepribadian pesantren dan bukan pondok lagi, namun pada akhrinya masyarakat sekitar menerima perubahan tersebut karena rnasyakat makin lama makin sadar akan pentingya penyesuaian pesantren dengan jaman yang semakin maju.

Setelah saat perkembangan ini sedikit maju dibidang kurikulum maka secara umum lembaga-lembaga pendiidkan yang ada di pondok pesantren al-Anwariyyah terbagi menjadi dua kelompok yaitu :

1. lembaga pendidikan yang mempergunakan kurikulum Departemen agama dan Kementerian Pendidikan dan Kebudayaan RI yaitu :
a. PAUD Al-Anwariyah
b. TK : TKA Al-Anwariyah
c. SD : Madrasah Ibtidaiyah al-Anwariyyah
d. SMP Al-Anwariyah
e. SMA Al-Anwariyah
f. Wajar Dikdas (Paket B dan Paket C)

2. Lembaga pendidkan yang menggunakan kurikulum lokal yang mempunyai ciri khusus kepesantrenan yaitu:

a. TPA al-Anwariyah

b. Seluruh Madrasah Diniyah disetiap tingkatan, antara lain:

1) Tsanawiyah Diniyah Hidayatul Mubtadi'in

2) Aliyah Diniyah Hidayatul Mubtadi'in

Adapun pelaksanaan lembaga pendidikan yang mempergunakan kurikulum Departemen Agama RI sama dengan kurikulum yang ada di madrasah madrasah lain yakni dengan mengikuti SKB tiga menteri.

Bila dilihat dari materi pendidikan yang ada pada kurikulum lokal ternyata mata pelajaran umum hanya terdapat satu bidang studi.yakni ilmu pendidikan sedangkan selebihnya itu adalah mata pelajaran agama 
sebagaimana yanag ada pada pondok pesantren lainya. Sehingga santri yang hanya belajar pada madrasah kurikulum lokal hanya sedikit pengetahuan umumnya,sedangkan santri yang belajar juga dimadrasah kurikulum Departemen Agama maka akan memiliki pengetahuan yang luas dibidang pendidikan.

\section{Penyempurnaan Administrasinya}

Dalam pengembangan sistem pendidikan dipondok pesantren, administrasi adalah suatu bagian dari beberapa komponen yang menentukan terbentuknya dan tercapainya suatu tujuan yang dicita-citakan.

Arti administrasi adalah kegiatan atau rangkaian kegiatan sebagai proses pengendalian usaha kerja sama kelompok manusia untuk mencapai tujuan bersama yang telah ditetapkan.

Salah satu yang dilakukan pondok pesantren al-Anwariyyah dalam pembenahan dipusatkan di admnistrasi pendidikan yang meliputi :

1. Buku induk fungsionaris pendidikan seperti pengurus, Ustadz, karyawan dan sebagainya

2. Buku Induk murid/Santri tiap-tiap angkatan

3. Buku Induk Keuangan yang memuat pokok-pokok keuangan dari waktu ke waktu

4. Arsip induk tentang semua kegiatan balai pendidikan baik berupa dokumen, surat, peresmian,surat masuk dan keluar, surat berharga dan kegiatan pendidikan lainya.

Selain dari bentuk-bentuk administrasi tersebut, pondok pesantren alAnwariyah juga membenahi administrasi lainnya, seperti :

1. Buku Daftar peresmian guru serta tiap-tiap tingakatan kelas

2. Buku daftar prestasi (gura,santri,dan termasuk daftar nilai santri

3. Buku daftar iuran

4. Arsip semua kegiatan praktek dan surat-surat berharga

5. Buku inventarsasi pola lengkap

Demikianlah keadaan administrasi yang ada dipondok pesantren alAnwariyyah pada saat penelitian dilakukan, dan cara kerjanya secara formal yang mengatur adminstrasi ditangani oleh pengurus secara bersama.

\section{Penyempurnaan Sarana dan Fasilitasnya}

Masalah fasilitas adalah merupakan faktor penunjang dalam menggerakan dan memajukan pondok pesantren . Apabila pondok pesantren banyak mengadakan pembaharuan maka konsekwensinya harus ditunjang dengan fasilitas atau sarana yang memadai.

Seperti halnya dengan penyempurnaan admnistrasi, penyempurnaan fasilitas yang dilakukan oleh pesantren yaitu secara bertahap dimana masalah fasilitas ini dikerjakan secara bersama-sama antara pengurus, hanya saja tehnisnya dipercayakan oleh K.H. Muqayim yang mendapat kepercayaan untuk menghimpun dana/donatur oleh K.H. Rokhmatullah.

Alasan dilakukanya pengembangan atau pembaharuan dibidang 
fasilitas diantaranya karena jumlah santri semakin banyak. Santri yang datang bukan hanya dari daerah Cirebon saja akan tetapi banyak yang datang dari daerah lain, disamping itu proses belajar mengajar tidaklah akan berjalan lancar jika tidak didukung dengan adanya fasiltas, karena fasilitas merupakan suatu elemen penting dalam proses belajar mengajar.

Dengan dilakukanya pengembangan dibidang fasilitas bukanya tidak ada hambatan yang dilakukan oleh pondok pesantren al-Anwariyyah, diantaranya adalah hambatan yang mengganjal adalah kurangnya dana karena pondok pesantren al-Anwariyah adalah lembaga pendidikan swasta yang tidak diberi bantuan oleh pemerintah.

Adapun penunjang dalam penyempurnaan fasilitas nya adalah masyarakat setempat banyak yang memikirkan pembangunan yang ada dipondok pesantren al-Anwariyah dalam artian ikut serta dalam membantu pembangunan yang ada dipondok pesantren.

Adapun fasilitas atau sarananya yang terdapat dipondok pesantren al-Anwariyah pada sat-saat sekarang ini meliputi bentuk-bentuk sebagai berikut :

1) Asrama santri 150 kamar (Putra+Putri)

2) Gedung Madrasah Permanen

3) Gedung Aula

4) Masjid

5) Kamar Mandi

6) Toilet

7) Dapur Umum

8) Lapangan Olah Raga

9) Gedung Waserda

10) Gedung Wartel

11) Ruang Perpustakaan

Demikian tadi merupakan hasil penelitian dan analisa daripada data yang telah penyusun peroleh dari Pondok Pesantren Al-Anwariyyah Desa Tegalgubug Lor Kecamatan Arjawinangun Kabupaten Cirebon tentang pembaharuan sistem pedidikan pondok pesantren yang meliputi : Pengajaran, kurikulum, administrasi dan fasilitas atau saranya.

\section{Simpulan}

Berdasarkan hasil penelitian yang telah peneliti peroleh baik itu melalui tehnik observasi, interviuw maupun melalui tehnik dokumenter tentang sistem pembaharauan pendidikan di pondok pesantren al-Anwariyyah, maka dapatlah kita ambil kesimpulan sebagai berikut :

1. Sistem dan metode pengajarannya mengalami perkembangan sejak tahun pelajaran 1987-1988 dalam bentuk - bentuk pembaharuan atau perkembangannya secara keseluruhan seperti dalam sistem bandongan, sistem sorogan, sistem klasikal maupun sistam kuliah umum, dalam pola operasional sistem tersebut pengajarannya digunakan beberapa metode yaitu : metode 
ceramah, metode tanya jawab, metode demontrasi, metode pemberian tugas atau metode Drill.

2. Kurikulum pondok Pesantren al-Anwariyyah dirumuskan pada tahun pelajaran 1987 - 1988 oleh pengurus pondok pesantren bidang pendidikan dalam keseluruhan pada pondok pesantren al-Anwariyyah dalam pelaksanaan pendidikannya dapat dilihat dari dua bentuk kurikulum yaitu :

a) Pelaksanaan pendidikan yang mengikuti ketentuan kurikulum lokal sebagai ciri khas kepesantrenan.

b) Pelaksanaan pendidikan dengan mengikuti ketentuan kurikulum Depatemen Agama RI dengan berpatokan pada SKB tiga mentri.

3. Sedangkan bidang Administrasi pondok pesantren al-Anwariyyah mulai mengalami perkembangan atau pembaharuan pada tahun pelajaran $\quad 1987$ 1988 oleh semua pengurus pondok pesantren.

4. Pembaharuan dibidang fasilitas dan sarana prasarana, pondok pesantren alAnwariyyah mengalami kemajuan yang signifikan, ini bisa kita lihat pada berdirinya asrama yang hunian, gedung madrasah yang permanen, sarana umum yang tersedia, dan sebagainya.

\section{DAFTAR PUSTAKA}

Agus, Bustanuddin, Sosiologi Agama, Padang: Andalas University Press, 2003

Ahmadi, Abu, Ilmu Sosial Dasar, Jakarta: PT. RINEKA CIPTA, 2003

Ali, Abdullah, Sosiologi Islam, Bogor; IPB PRESS, 2005

Al-Munawar, Said Aqi Husen, Islam Humanis, Jakarta: PT. Moyo Segoro Agung, 2001

Damami, Muhammad, Makna Agama Dalam Masyarakat Jawa, Yogyakarta: LESFI, 2001

Departemen Agama, Islam Untuk Disiplin Ilmu Sosiologi, Dirjen Pembinaan Kelembagaan Agama Islam, 1997

Dhofier, Zamakhsari, Tradisi Pesantren, Studi tentang Pandangan Hidup Kiyai, Jakarta:LP3ES, 1994

Fathoni, Abdurrahmat, Antropologi Sosial Budaya Suatu Pengantar, Jakarta: PT. RINEKA CIPTA, 2006

Khaeroni, Islam DanHegemoni Sosial, Jakarta: MEDIACITA, 2003

Koentjaaningrat, Pengantar Ilmu Antropologi, Jakarta: AKSARA BARU, 1986

Lexy Moeleong.Metodologi Penelitian Kualitatif, Bandung : Remaja Rosdakarya. 2004

Mahfudh, Sahal, Pesantren Mencari Makna, Jakarta: Pustaka Ciganjur \& Keluarga

Mas'ud, Abdurrahman, Intelektual Pesantren, Perhelatan Agama dan Tradisi, Yogyakarta:LKiS, 2004

Madjid, Nurcholis, Bilik-Bilik Pesantren, Sebuah Potret Perjalanan, Jakarta: Paramadina, 1997

Moesa, Ali Mashan, Nasionalisme Kiai, Konstruksi Sosial Berbasis Agama, Yogyakarta: LKiS, 2007 
Maumunah, Binti, Tradisi Intelektual Santri Dalam Tantangan dan Hambatan Pendidikan Pesantren di Masa Depan, Yogyakarta: Teras, 2009

Nana Syaodih Sukmadinata, Metodologi Penelitian Pendidikan, Bandung: PT. Remaja Rosda Karya, 2005

Nasir, M.Ridwan, Mencari Tipologi Format Pendidikan Ideal Pondok Pesantren Di Tengah Arus Perubahan, Yogyakarta: Pustaka Pelajar, 2010

Rochajat Harun. Metode Penelitian Kualitatip untuk Pelatihan. Bandung: CV Mandar Maju, 2007

Siroj, Said Aqil, Tasawuf Sebagai Kritik Sosial, Jakarta: SAS Foundation, 2012 , Islam Kebangsaan, Jakarta: FATMA Press, 1999

Suharto, Edi , Kebijakan Sosial, Bandung: Alfabeta, 2011

Sumarnonugroho, Sistem Intervensi Kesejahteraan Sosial, Yogyakarta:PT. Hanindita, 1987

Sugiyono.Memahami Penelitian Kualitatif, Bandung: Alfabeta.2007 , Metode Penelitian Pendidikan Pendekatan Kuantitatif, Kualitatif, dan RE $D$, Bandung: Alfabeta.2009

Sutrisno Hadi. Metodologi Research I, Yogyakarta: Andi Offset, 1993

Ziemek, Manfred, Pesantren dalam Perubahan Sosial, P3M, 1986

Zuhri, KH. Saifudin, Berangkat dari Pesantren, Yogyakarta:LKIS, 2010 